\title{
Where metaphors really come from: Social factors as contextual influence in Hungarian teenagers' metaphorical conceptualizations of life
}

\author{
Réka Benczes \\ Corvinus University of Budapest \\ Bence Ságvári \\ Hungarian Academy of Sciences, Institute of Sociology
}

\begin{abstract}
When it comes to metaphorical conceptualizations of life, previous cognitive linguistic research has identified cultural history as the single most important factor in the selection of the source domain. Accordingly, Hungary had to constantly battle for survival, prompting Hungarians to think of life primarily in terms of struggle and compromise, resulting in a more negative mindset towards life. We investigated the validity of this claim by drawing on a nationwide survey of Hungarian teenagers. Three main findings of the research are presented in the paper. First, the identified metaphors were of a general character and no particularly prevalent, negative conceptualizations emerged; Hungarian teenagers conceptualize life primarily as GAME, FOOD, JOURNEY, CHALLENGE, PLANT and ROLLERCOASTER. Second, social factors - type and location of school, socio-economic status and media consumption - can have an effect on the selection of source domains, thus lessening the importance of cultural history in shaping metaphorical conceptualizations of life. Third, social factors influence speakers' overall inclination toward metaphorical usage. Our results suggest that inclination to verbalize metaphorical conceptualizations is not all-pervasive throughout the whole linguistic community, but is constrained by type of school (at the secondary level), mother's level of education, academic performance and reading habits.
\end{abstract}

Keywords: life, Hungarian, conceptual metaphor, social factors, contextual influence

\section{Introduction}

Life - besides love, death, fear and desire - is possibly one of the greatest enigmas of human existence. We all grapple with understanding the "meaning" of life - i.e., with the task of finding a suitable narrative with which our actions and the events that we experience can be interpreted and accounted for. Literature offers a vast array of such narratives: the Greek poet Constantine Cavafy, in his poem "Ithaka”, compared life to the long journey of Odysseus to his home, the island of Ithaka:

As you set out for Ithaka hope the voyage is a long one, full of adventure, full of discovery.

Laistrygonians and Cyclops, angry Poseidon - don't be afraid of them: you'll never find things like that on your way as long as you keep your thoughts raised high, as long as a rare excitement stirs your spirit and your body. ${ }^{1}$

1 Translated from the Greek original by Edmund Keeley and Phillip Sherrard. Source: http://www.cavafy.com/poems/content.asp?cat=1\&id=74 (accessed: 10 June 2016). 
The poem depicts life as a purposeful journey, in which the traveller - Odysseus - tries to reach his destination, Ithaka. The adventures that Odysseus has along the journey are the adventures that we experience in life, and which make life interesting and exciting. The end of the journey - Ithaka - is death. Cavafy's understanding of life, therefore, is based on a very specific narrative - that of the journey of Odysseus. However, the understanding of life as a journey is by no means particular to Cavafy, or even literature for that matter. It is a very common, possibly ubiquitous metaphor that is pervasive in everyday language and thought (Lakoff and Johnson 1980). As laid out by Lakoff and Johnson (1980) in what has become known as Conceptual Metaphor Theory (CMT), abstract concepts, such as life, can only be understood or made sense of by relying on more concrete concepts, resulting in conceptual metaphors - such as LIFE IS A JOURNEY ${ }^{2}$ - that serve as the "principal vehicles for understanding” (Lakoff and Johnson 1980: 133). ${ }^{3}$ These conceptual metaphors are manifested in language, in linguistic metaphorical expressions; the conceptual metaphor LIFE IS A JOURNEY is made evident in everyday expressions such as "life taking an unexpected direction”, "knowing where one’s going in life”, “doing things in a roundabout way", "be at a crossroads”, etc. The reason why Cavafy's poem makes sense to us and resonates with our own experiences is because LIFE IS A JOURNEY is a basic and conventionalized metaphor ${ }^{4}$ (which is then elaborated on in an original and creative manner by Cavafy).

Yet life as a journey is but one possible conceptualization for understanding life. Lakoff and Turner (1989) note that there are a number of basic metaphors for understanding life (and conversely death), which all focus on different aspects, thus resulting in different inferences. These basic conceptualizations of life are the following (based on Lakoff and Turner 1989 and Kövecses 2002/2010):

\author{
LIFE IS A JOURNEY \\ LIFE IS A (GAMBLING) GAME \\ LIFE IS A BUILDING \\ LIFE IS A BURDEN \\ LIFE IS A PLAY \\ LIFE IS A PRECIOUS POSSESSION \\ LIFE IS A SPORTING GAME \\ LIFE IS A STORY \\ LIFE IS BONDAGE \\ LIFE IS FIRE \\ LIFE IS LIGHT \\ PEOPLE ARE PLANTS / HUMAN LIFECYCLE IS THE LIFECYCLE OF A PLANT
}

As explained by Kövecses (2002/2010), the reason why a target concept is understood through a number of different source domains is because a single source concept is unable to cater to all aspects of a target concept. Given the fact that a target concept such as life can be

2 As is customary in cognitive linguistic literature, we will use small caps for conceptual metaphors and source domains.

3 The basic premise of the paper is that conceptual metaphors are a part of the ordinary speaker's conceptual system, and provide a means of organizing knowledge about the world. Their psychological reality, however, has been a question of much debate, the scope of which falls outside of the present paper. Nevertheless, there is some evidence for the psychological reality of the LIFE IS A JOURNEY metaphor. In a series of psycholinguistic experiments, Katz and Taylor (2008) have found evidence for the LIFE IS A JOURNEY conceptual metaphor in both semantic and episodic memory (though it was less salient in the latter).

4 Attested in a number of languages, such as English and Hungarian (see Kövecses 2002) and Turkish (Özçalişkan 2003) among others. 
conceptualized by a host of source domains - such as JOURNEY, GAME, PLAY, FIRE, etc. - the puzzle is the following: What motivates speakers to choose one metaphor over the other?

This question was elaborated on in detail in Kövecses' (2015) most recent monograph, Where Metaphors Come From: Reconsidering Context in Metaphor, in which it is claimed that metaphorical conceptualizations arise from global contexts on the one hand, and local contexts on the other; these contexts are then differentiated into further levels (see pp. 100112). Thus, the global context (which Kövecses understands very broadly as the world around us) is made up of the immediate physical environment, the social setting, the cultural setting, differential memory, and differential concerns and interests. The local context - broadly speaking - is the discourse situation itself, which includes both the physical setting, as well as the participants' knowledge about the topic and the main entities in the discourse. These motivational forces, taken together, are referred to by Kövecses as "contextual influence" (p. 71), and constantly mould our metaphorical conceptualizations.

Which of these, however, plays a more significant role in making sense of life? Previous cognitive linguistic research on the topic (Kövecses 2005; Schmidt and Brdar 2012; Kuczok 2017, in press) places the emphasis on cultural history (also referred to as "differential memory” by Kövecses 2005). ${ }^{5}$ Thus, Hungarians tend to take a more negative, passive, fatalistic perspective on life, as opposed to American English speakers, who have a more positive, active and engaged approach to life. The difference, as explained by the available cognitive linguistic research, can be accounted for by cultural history: in the course of the 1,100 year-long history of Hungary, the country had to wage constant battles for survival, wedged between Germanic-speaking peoples in the West, and Slavic-speaking peoples in the East. This has had an imprint on Hungarian cultural and social history, prompting Hungarians to think of life primarily in terms of struggle and compromise.

It is a commonplace within linguistics that languages vary considerably along the social dimension (see for example Wardaugh and Fuller 2015). Accordingly, the selection of a particular source domain should be heavily motivated by social factors. Kövecses (2005: 88), in fact, does acknowledge the significance of the social dimension in the variation of metaphors, as these variations are rooted in "the experiences of the people divided by these dimensions". If metaphors represent human experience, then it can be expected that both conceptual and linguistic metaphors will "vary according to these social divisions" (Kövecses 2005: 88), which Kövecses understands as pertaining to gender, age and social class.

Nevertheless, no such divisions have been considered in the case of life metaphors within cognitive linguistic research. We fully agree with Dirven (2005: 40), according to whom language variation is still "wildly absent from cognitive-linguistic research, whereas in fact it ought to be at the heart of its research agenda".

The aim of the present research was twofold. On the one hand, we wished to investigate the validity of previous cognitive linguistic research regarding the "more negative" mindset of Hungarians, as represented by conceptual metaphors involving struggle and compromise. On the other hand, we wished to examine the degree to which social factors might influence the selection of a particular source domain for the target domain life. Drawing on the results of a nationwide survey of Hungarian teenagers carried out in the autumn of 2015, we hypothesized that 1) the identified metaphors would be of a general character and no particularly prevalent, negative conceptualizations would emerge; and 2) social factors - understood broadly here as socio-demographic characteristics, such as age, gender, socio-economic status, education, etc. - would influence the selection of a particular concept as a source domain for the conceptualization of life, thus questioning the overall dominance of cultural history. Our

5 Kövecses (2005: 241) uses the term memory here to refer to events that occurred in history and which are remembered through the "collective unconscious" of a group. 
study is novel on a number of accounts. As far as we know, this is the largest survey ever conducted within the literature on the metaphorical conceptualization of life (890 analyzable responses). It is also the first such study to employ a survey-based data collection method as traditionally applied in sociology in order to investigate the interplay between social factors and metaphorical conceptualization. In fact, the rich research tradition within sociology for cross-national and cross-sectional value and attitude analysis (Rokeach 1973; Schwartz 2007) might provide useful insights for cognitive linguistic studies that focus on social factors.

Besides the evident implications of the current study for general metaphor research (both theoretical and empirical - with regard to the significance of the latter for cognitive linguistic investigations, see Gibbs 2007), our research also aims to tap into cognitive sociolinguistic investigations by focusing on the factors that result in language-internal variation of metaphor usage. As emphasized by Geeraerts et al. (2010a: 6), despite the growing interest within cognitive linguistics for socio-variationist studies (see, for example, Kristiansen and Dirven 2008; Geeraerts et al. 2010b; Pütz et al. 2014), it still remains a relatively understudied area.

The structure of the paper is the following: After the Introduction, Section 2 discusses previous cognitive linguistic studies on the conceptualization of life in Hungarian (as opposed to American English conceptualizations). Section 3 describes the methodology of the research, while Section 4 analyzes the results. The last, fifth, section sums up the main findings of the study.

\section{Previous research on the metaphorical conceptualization of life in Hungarian}

As far as we know, the only available study on Hungarian metaphorical conceptualizations of life comes from Köves (2002; cited in Kövecses 2005), who asked twenty Hungarians and twenty Americans (living in Hungary) to write a one-to-two page essay on life. ${ }^{6}$ Despite the fact that the word metaphor did not appear in the instructions, and the participants were not asked to express their thoughts by resorting to metaphor, the study was a success in the sense that all of the essays drew on metaphors either implicitly (via figurative expressions) or explicitly (by explaining life through the use of an analogy). Köves analyzed the individual texts by identifying the conceptual metaphors underlying the metaphorical linguistic expressions and drew up a list of the ten most frequently occurring conceptual metaphors in the Hungarian and American essays. These metaphors are presented in Table 1.

Table 1. The 10 most frequent Hungarian and American English conceptualizations of LIFE that emerged in the research of Köves (2002; cited in Kövecses 2005).

\begin{tabular}{lll} 
& \multicolumn{1}{c}{ Hungarian } & \multicolumn{1}{c}{ American English } \\
$\mathbf{1}$ & STRUGGLE/WAR & PRECIOUS POSSESSION \\
$\mathbf{2}$ & COMPROMISE & GAME \\
$\mathbf{3}$ & JOURNEY & JOURNEY \\
$\mathbf{4}$ & GIFT & CONTAINER \\
$\mathbf{5}$ & POSSIBILITY & GAMBLE \\
$\mathbf{6}$ & PUZZLE & COMPROMISE \\
$\mathbf{7}$ & LABYRINTH & EXPERIMENT \\
$\mathbf{8}$ & GAME & TEST \\
$\mathbf{9}$ & FREEDOM & WAR \\
$\mathbf{1 0}$ & CHALLENGE & PLAY
\end{tabular}

The top three Hungarian source domains were STRUGGLE/WAR, COMPROMISE and JOURNEY, as opposed to the American PRECIOUS POSSESSION, GAME and JOURNEY (Kövecses 2005: 8485). Accordingly, Hungarians wrote about life as battles that have to be won and people

6 No information was provided on the socio-demographic background of the participants. 
having to fight throughout life. At the same time, Americans described life as the most precious commodity and something that we have to cherish and take care of. Regarding the second most frequently used metaphors on the respective lists, Hungarians wrote about accepting life as it is given to them, as opposed to the Americans, who wrote about the stakes being high and making their life as good as possible within the limits and rules of this game. As for the JOURNEY metaphor, which appears as the third most frequently used conceptualization on both of the lists, the emphases were different in the two languages. Americans mentioned its goal-orientedness (e.g., striving to reach our destination in life), whereas Hungarians focused on the obstacles along the way (e.g., the road sometimes being buтpy).

While many of the metaphors were shared - COMPROMISE, GAME, JOURNEY and WAR featured on both lists - these shared metaphors ranked quite differently in the respective lists (Kövecses 2005: 84-85). GAME, for instance, figured as only the eighth most popular source domain in the Hungarian essays, while it was the second most frequently used metaphor in the American conceptualizations. Further, COMPROMISE was only sixth on the American list, while it was the second item on the Hungarian one.

Thus, Table 1 is not just a simple ranking. ${ }^{7}$ Instead, "[i]t suggests that Americans and Hungarians have different concepts of life and that the differences arise as a result of the different preferences in the use of largely overlapping source domains” (Kövecses 2005: 85; emphasis as in original). In other words, the source domains that are available to both linguistic communities might be more-or-less similar; nevertheless, the differences in attitude towards life arise from which of these source domains are used more often by the respective linguistic communities and thus which become more established and more entrenched as conceptual metaphors.

Somewhat similar results emerged in a comparative study on the linguistic metaphorical expressions of the LOVE IS A JOURNEY conceptual metaphor in Hungarian and American English, where the Hungarian expressions suggested a more passive, fatalistic, insecure and introverted attitude to love in general, as opposed to the American data, which implied a more active, individualistic, success-oriented and extroverted attitude (Kövecses 2005). These results were corroborated by Schmidt and Brdar (2012), who analyzed the universality of the LIFE IS A (GAMBLING) GAME metaphor by comparing the linguistic manifestations of the metaphor in American English, Croatian and Hungarian. A general pattern emerged in the data: both the Hungarian and the Croatian expressions had a tendency to draw on the concept of lottery (which is a more passive type of gambling game), while the American English expressions were mostly motivated by more active types, such as dice and card games, where the player needs to make constant decisions and also assess the chances and risks. Schmidt and Brdar reasoned that the difference in the metaphorical linguistic expressions reflect a different mentality toward life in general: while Americans have a more active approach and wish to remain in control of their lives, Croatians and Hungarians are more passive and accept things as they are. ${ }^{8}$

While there is no clear-cut evidence for the psychological reality of the Hungarian mindset outlined above (as opposed to the American one), ${ }^{9}$ there are some tentative results from

7 No information was provided on the number of tokens of the respective metaphors.

8 The more active - as opposed to passive - attitude of Americans towards life emerges in other linguistic examples as well. Consider for example, the preference of take versus have in phrases such as take a bath and take a walk (British English has a preference for have; see Wierzbicka 1988).

9 Nevertheless, research on the analysis of national symbols - such as national anthems - and their correlations with suicide rates offer an interesting perspective on the issue. See, for example, Lester and Gunn (2011a, 2011b) and Vörös et al. (2012). 
sociology in the form of cross-national value surveys (on their history and application see e.g. Hofstede 2001; Inglehart 1997; Knack and Keefer 1997; Pryor 2005), such as the World Values Survey, that do corroborate some of these findings. One of the questions of the WVS is concerned with the feeling of happiness and general satisfaction with life. As Figures 1a and $1 \mathrm{~b}$ show, ${ }^{10}$ the Hungarian and the American responses show quite different trends with respect to these questions.

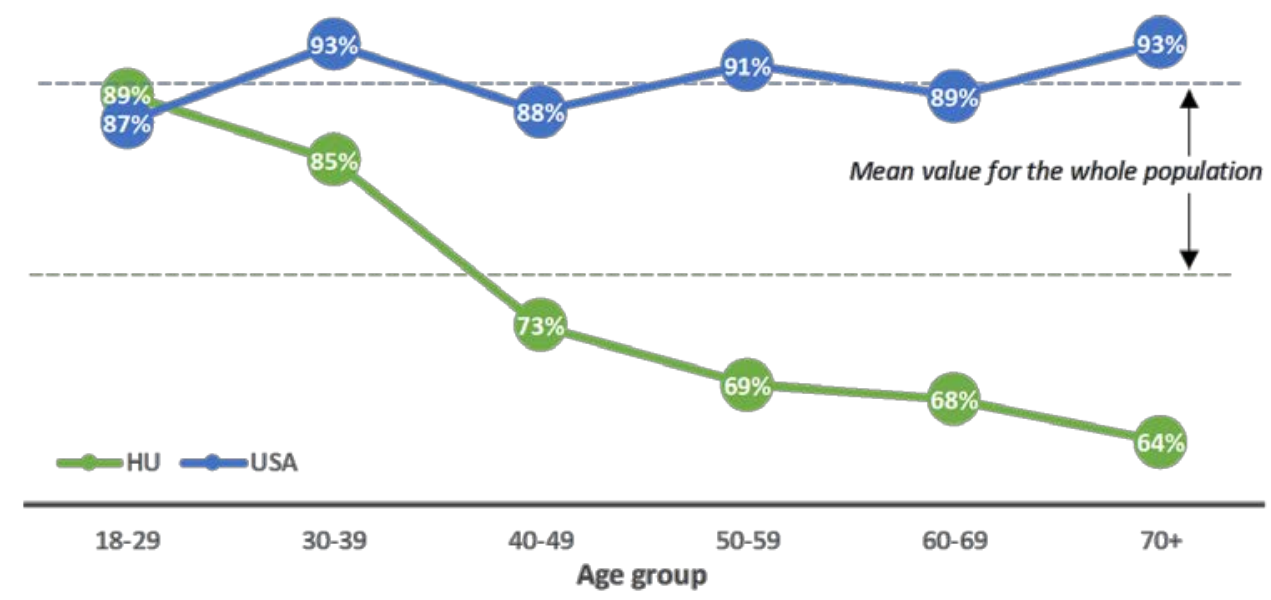

Figure 1a. Percentage of those who consider themselves to be "very" or "rather" happy.

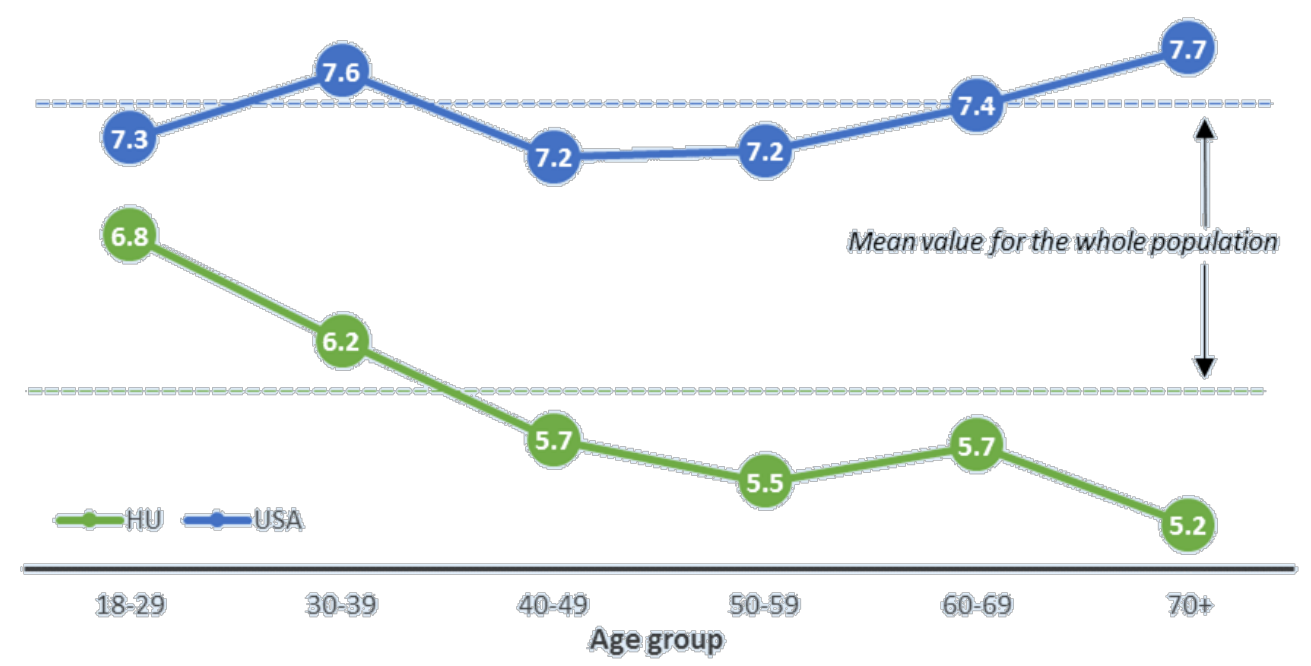

Figure 1b. Average life satisfaction values on 1-10 scale. 1: completely dissatisfied; 10: completely satisfied.

While the American data reflect a stable and even trend, implying that the level of happiness and satisfaction with life remains constant over all the age groups, the Hungarian data show a different trend, with figures declining sharply in every single age group. Yet, where there is no significant difference is the youngest age group (18-29 years). This is the generation in Hungary which was born after the regime change from communism to

10 Source of data: World Values Survey, 5th wave (Hungary: 2009; USA: 2011). 
capitalism. Such data suggest that how life is perceived in Hungary - at least among the younger generations - might not be negative at all and is rather a reflection of the global concerns and interests of present-day youth.

Schmidt and Brdar (2012) have in fact reported on such results when they checked the frequency of the metaphors LIFE IS A GAME versus LIFE IS A STRUGGLE on Google in both Hungarian and Croatian. They found that - contrary to the results reported by Kövecses (2005) -, the former (LIFE IS A GAME) was twice as prevalent as the latter (LIFE IS A STRUGGLE) in both languages. ${ }^{11}$ Schmidt and Brdar (2012) reasoned that their findings reflected the attitude of the Gaming Generation - in other words, people who grew up in the 1980s playing video and computer games, and who are now proficient users of the internet. Further, in an association test where Hungarian native-speaker subjects had to list five things that came to their mind in connection with life, the most frequent semantic domains that emerged were HAPPINESS, DEATH, LOVE and FAMILY \& FRIENDS. The concepts were too vague and neutral to suggest any culture-specific influence; instead, they reflected general concerns about human existence (Hegedüs 2015).

Schmidt and Brdar's (2012) and Hegedüs' (2015) studies imply that Hungarians, especially the younger generation, might not have such a negative mindset after all. However, the results of both of these studies are very tentative and non-representative and do not say much with respect to how Hungarian youth conceptualize life nowadays and why they conceptualize it the way they do. Thus, in order to fill in this substantial gap in the available research, we surveyed Hungarian teenagers on how they conceptualized life by asking them the following question: "What would you compare life with and why?" (Methodological details are provided in the next section.) We carried out the survey with the aim of answering the following two main research questions: 1) What conceptual preferences do Hungarian teenagers have for life? 2) What sociological factors can be identified as being influential in the emergence of metaphorical conceptualizations? In line with these research questions we hypothesized that 1 ) the identified metaphors would be of a general character and no particularly prevalent, negative conceptualizations would emerge; 2 ) social factors would influence the choice of a particular concept as a source domain for conceptualizing life; and 3) the inclination to verbalize a concept as a source domain for life is not equally all-pervasive throughout a linguistic community but is dependent on social factors.

\section{Methodology}

In order to acquire as much data as possible, we collaborated with a representative, nationwide research project carried out in the second half of 2015 on the media and internet use of Hungarian youth. The self-administered questionnaire contained 76 questions revolving primarily around media- and internet-related themes (such as how subjects spent their free time, what electronic devices they had at home, what sort of social media and online networks they were involved in, etc.). ${ }^{12}$ In line with these queries, we included the following question in the survey - with the aim of collecting source domains for life: "People think about life in very different ways. What would you compare life with and why? Please complete the following sentence. Note that there are no right or wrong answers; you can write anything that comes to your mind: Life is like ..., because ...”

Needless to say, we are aware of the limitations that this particular method entails. The question elicited from the participants only a single concept (as an explicit comparison for life), and no detailed elaboration was further required from them. Such an approach implies

11 Schmidt and Brdar (2012) searched for the sequences "life is a game” and "life is a struggle” (as linguistic manifestations of the respective metaphors).

12 The results of this research do not form part of the present paper. 
that some of the answers might be spontaneous, spur-of-the-moment responses, and not the result of a conscious, deliberated reflection on what life is and how it is understood (note that the survey itself had 75 other questions in it, too, which were unrelated to our query). Thus, our method is in stark contrast to previous studies where the subjects had to write an essay, and had definitely more time and space to think and write about life in general. ${ }^{13}$

Nevertheless, we believe that this limitation is made up for by two significant factors. First, as far as we know, never before has such a large-scale research been carried out on any metaphorical conceptualization (including life for that matter). The entire questionnaire was disseminated among 1,168 seventh graders (primary school pupils; mean age: 13 years); and 1,426 eleventh graders (secondary school students; mean age: 17 years), representing three different types of secondary schools, which were the following:

1) vocational schools, which provide specialist training in a particular profession, such as a mechanic, a carpenter, etc.;

2) secondary vocational schools, which also provide specialist training but on a higher level than vocational schools, and which also offer students the "maturation exam" at the end of their studies, needed to enter higher education;

3) grammar schools, which are academically the most prestigious institutions at the secondary level, geared toward students who wish to enter higher education.

The total sample size was 2,594 students from 128 institutions, coming from two, nationally representative sub-samples. Second, the survey also made it possible to identify the respondents' socio-demographic background (i.e., age, gender, location, socio-economic status (SES), household composition, etc.), so that correlations (if any existed) between preferences for metaphorical source domains and sociological variables could be identified. Also, and more importantly, the motivation of metaphorical conceptualizations could be studied by focusing on the socio-contextual factors of the respondents.

As a first step in the data analysis, we filtered out those responses where the question was left blank (i.e., no text was provided) or where the participant did provide an answer, but this could not be coded as a source domain for life. In such cases the answer was, for example, an adjective ("good”, "bad”, "interesting”, "boring”, etc.) or unrelated to the question ("our financial status is terrible”). In the end, we had 890 analyzable items, i.e., responses where the subject provided an answer that could be identified as a source domain (and accordingly a metaphor) for life (see Appendix 1). The answers were quite wide-ranging; these included single nouns (e.g., "adventure”, “football”, "book”), phrases (e.g., "a burning house”, “a constant cycle", "a box of chocolates"), similes ("like a movie”, "life is like a tomato") and sometimes even complete sentences ("Life is like a game; play!", "Life is a labyrinth and you have to find your way out"). Nevertheless, what was common to all of these responses was the presence of an identifiable concept ("book”, “cycle”, “movie”, "tomato”, "game”, "labyrinth”, etc.), which we then coded as a source domain for life.

One possible reason why the number of analyzable responses dropped from 2,594 to 890 might be that the question was open-ended. This was, however, a deliberate choice on our part. After all, we could have provided the respondents with a list of ca. 10 items (based on previous metaphor studies) from which they could have chosen their answer. While this method might have solicited more responses, it would have also biased the data, as it would have been a subjective decision on our part which source domains the subjects could have chosen and it would have been very difficult (if not impossible) to justify our selection. Most

13 Note also that due to the nature of the data collection we were not able to control the potential effect of inherent priming in the questionnaire. However, we reckon that the great diversity of topics and questions prevented any systematic bias towards the emergence of certain metaphors. 
importantly, however, by leaving the question open we were also able to investigate whether the social context had any influence on our respondents' inclination and/or ability to verbalize their outlook on life via a metaphor.

\section{Results}

\subsection{Hungarian teenagers' metaphorical conceptualizations of life}

As a first step, we examined what were the major metaphorical conceptualizations of life in the responses. In sum, we identified 161 metaphor types. Some explanation as to the data is necessary. First of all, for the sake of simplicity and better comparison, we have categorized certain basic- or subordinate-level concepts under higher-level ones. For example, in the case of FOOD, the respondents provided a large variety of specific food terms (box of chocolates, bun, goulash soup, pizza, pancake, pea soup, etc.), which we have grouped under the superordinate category of FOOD. Similarly, the source domain of ANIMAL includes a wide variety of animal species - birds, butterflies, horses, unicorns, ants, dogs, wolves, etc. ${ }^{14}$ While it might be claimed that such a method glosses over the details, its benefit is that it is able to shed light on more general themes of life conceptualizations, and also opens up the possibility for comparison with previous studies. Results are presented in Table 2. The column on the right-hand side presents the number of examples that we were able to find for a particular conceptualization. We have decided to include only those concepts in the analysis that had at least a minimum of 5 tokens and thus an occurrence of more than $0.5 \%$ in the sub-sample of teenagers who provided a metaphor.

Table 2. Hungarian teenagers’ responses: Life is a(n)...

\begin{tabular}{l|lcc} 
No. & Metaphor & No. of tokens & \% \\
\hline $\mathbf{1}$ & game & 79 & 8.9 \\
$\mathbf{2}$ & food & 56 & 6.3 \\
$\mathbf{3}$ & journey & 50 & 5.6 \\
$\mathbf{4}$ & challenge & 47 & 5.3 \\
$\mathbf{5}$ & plant & 44 & 4.9 \\
$\mathbf{6}$ & rollercoaster & 41 & 4.6 \\
$\mathbf{7}$ & animal & 29 & 3.3 \\
$\mathbf{8}$ & movie & 28 & 3.1 \\
$\mathbf{9}$ & opportunity & 25 & 2.8 \\
$\mathbf{1 0}$ & adventure & 24 & 2.7 \\
$\mathbf{1 1}$ & cycle & 24 & 2.7 \\
$\mathbf{1 2}$ & struggle/war & 20 & 2.2 \\
$\mathbf{1 3}$ & gift & 18 & 2 \\
$\mathbf{1 4}$ & story & 17 & 1.9 \\
$\mathbf{1 5}$ & book & 15 & 1.7 \\
$\mathbf{1 6}$ & sports & 14 & 1.6 \\
$\mathbf{1 7}$ & treadwheel & 14 & 1.6 \\
$\mathbf{1 8}$ & happiness & 12 & 1.3 \\
$\mathbf{1 9}$ & time & 12 & 1.3 \\
$\mathbf{2 0}$ & sea & 11 & 1.2 \\
$\mathbf{2 1}$ & weather & 11 & 1.2 \\
& & &
\end{tabular}

14 Needless to say, further relationships can be established among the metaphors. LIFE IS A MOVIE can be related to LIFE IS A BOOK, LIFE IS A STORY Or LIFE IS A DREAM in that all of them are sequential narratives. 
Cognitive Linguistics, Volume 29, Issue 1, Pages 121-154, ISSN (Online) 1613-3641, ISSN (Print) 0936-5907, DOI: https://doi.org/10.1515/cog-2016-0139.

\begin{tabular}{l|lcc}
$\mathbf{2 2}$ & dream & 10 & 1.1 \\
$\mathbf{2 3}$ & faeces & 9 & 1 \\
$\mathbf{2 4}$ & play & 7 & 0.8 \\
$\mathbf{2 5}$ & river & 7 & 0.8 \\
$\mathbf{2 6}$ & building & 6 & 0.7 \\
$\mathbf{2 7}$ & competition & 6 & 0.7 \\
$\mathbf{2 8}$ & labyrinth & 6 & 0.7 \\
$\mathbf{2 9}$ & learning & 6 & 0.7 \\
$\mathbf{3 0}$ & work & 6 & 0.7 \\
$\mathbf{3 1}$ & hell & 5 & 0.6 \\
$\mathbf{3 2}$ & suffering & 5 & 0.6
\end{tabular}

A quick glance at Table 2 makes it immediately evident that the metaphorical conceptualizations of contemporary Hungarian teenagers is closer to that of the metaphorical conceptualizations of American English speakers as reported by Köves (2002; cited in Kövecses 2005): two out of the three top metaphors in the respective data sets are shared (GAME and JOURNEY). At the same time, STRUGGLE/WAR and COMPROMISE - which appeared among the top three choices among the Hungarian respondents in 2002 - did not make it into even the top ten of the most frequent conceptualizations in the 2015 data (in fact, COMPROMISE did not show up at all in our data); this, however, might be explained by the relatively young age of the respondents, who have not yet had experienced as many difficulties in life or circumstances in which they had to accept compromise as, for instance, adults.

The LIFE IS A GAME metaphor was a very popular conceptualization among our respondents, as it surfaced as the most frequent metaphor, accounting for nearly $9 \%$ of the data. ${ }^{15}$ The answers that we received often relied on the world of computer games: "if you do something well, you can get to a higher level", "if you mess up, you die”, "you need to collect points". Nevertheless, many of the answers applied to GAME as a more general (superordinate) category (applicable to both computer games and other types of games): "some win, some lose”, "you can do whatever you like with it", "you just need to know the rules”, etc. Specific games showed up relatively rarely, these being chess and gambling games (both $3 \%$ out of the total for the larger category of GAME), and card games and board games (both 2.5\%).

Quite unexpectedly, the second most frequent metaphorical conceptualization was FOOD, which did not show up as a potential source domain in any of the previous researches. Nevertheless, nearly a quarter of the answers within this category likened life to a "box of chocolates"; our respondents explained their choice by saying "you never know what you'll get”. This is in fact nearly a word-by-word quote from the movie Forrest Gump (1994), where the main protagonist says the following, "Mama always said life was like a box of chocolates. You never know what you're gonna get". ${ }^{16}$ The use of this simile might indicate the direct effect of American popular culture on Hungarian; the latter does not have any conventionalized phrase or expression that is a manifestation of the LIFE IS A BOX OF CHOCOLATES metaphor. ${ }^{17}$ Apart from the box of chocolates, all sorts of food showed up within this category - especially Hungarian staple foods such as pea soup and goulash. In

15 Note that the percentage of items in the survey that focused on games and gaming was minimal, accounting for only $2.8 \%$ of the total, thus ruling out the possibility of potential priming effects.

16 Source: https://en.wiktionary.org/wiki/life_is_like_a_box_of_chocolates (accessed 18 June 2016).

17 Instead, the same figurative meaning is captured by the expression "life is full of surprises"; nevertheless, SURPRISE did not figure among the answers. 
these cases the main meaning focus (Kövecses 2002/2010: 146) was unpredictability, similarly to a box of chocolates - you never knew what you might find on your plate. International food also appeared, such as muffin, carrot cake, candy, chocolate, etc., where the main reason behind the selection was based on optimism - students chose these source domains "because they taste good".

The third most frequent metaphorical conceptualization out of the total data was JOURNEY, accounting for $5.6 \%$ of the responses. Some of the answers were quite elaborate and rested upon a number of conventionalized mappings between the source and target domains, explaining that there were multiple paths to choose from, one needed to make decisions as to which way to go, and challenges along the way had to be tackled. In fact, CHALLENGE was the fourth most common metaphorical conceptualization (it ranked as the 10th most frequent metaphor in 2002 among the Hungarian data). In their answers, the respondents typically highlighted the fact that life was full of obstacles and was difficult (e.g., "there will be difficult times, and we have to meet these challenges"; "there are a lot of difficulties", etc.), but there was an optimistic note to these answers as well, emphasizing perseverance and never giving up ("you need to persevere to reach your dreams"; "there will always be difficulties but it depends on us whether we can overcome these"). Similar optimism could be detected in the answers that conceptualized life as an OPPORTUNITY ("every day is a new opportunity"; "we can try anything we want", etc.), which ranked as the ninth most popular metaphor in our data (and was the fifth most popular one in 2002).

It seems then that optimism is a recurring theme within the answers - our Hungarian teenagers have a more-or-less positive outlook on life, which is in line with the World Value Survey results (see Figures 1a and 1b). Besides this optimism, however, changeability (and uncertainty to some degree) also appeared in a couple of the metaphors, as yet another frequent theme. Apart from the already mentioned FOOD, students who likened life to a rollercoaster ride (which was the sixth most frequent metaphor on our list), emphasized its quickly changing nature (“one time you're up, one time you're down"). Changeability showed up as the main meaning focus in other metaphors as well, such as RIVER, SEA, SPORTS, WEATHER and even ADVENTURE (in the latter case this feature was construed as something “exciting”).

Regarding the conventionality of metaphors used by Hungarian teenagers in 2015, many of the top ten metaphors were unique to this particular survey - FOOD, PLANT, ANIMAL, ROLLERCOASTER, MOVIE, CYCLE and ADVENTURE did not appear on any of the 2002 lists. With regard to the PLANT conceptualizations, the answers typically drew on the HUMAN LIFECYCLE IS THE LIFECYCLE OF A PLANT metaphor ("we are born, we grow and then we die"; "it dries up and we also die", etc.); this feature of cyclicity was the main meaning focus with regard to the CYCLE metaphor, too. Both ANIMAL and MOVIE are unconventional source domains in that they are not mentioned in Lakoff and Turner's (1989) or Kövecses' (2002/2010) lists either. With regard to the former, the animals that appeared in the answers included bird, horse, unicorn, wolf, rhino, sea cucumber, ant, turtle, snail, sloth and goat among others - their motivation might be linked to the remnants of childhood stories, where there is an abundance of personified animals. The emergence of the MOVIE metaphor might be related to the influence of the visual media on contemporary youth culture. In fact, the MOVIE metaphor might be a novel instantiation of the LIFE IS ENTERTAINMENT metaphor, which has been described as a foundational metaphor of American culture by Kövecses (2005: 186).

\subsection{Social factors as contextual influence in the metaphorical conceptualization of life}

What social factors, however, motivate the choice of metaphor when it comes to the conceptualization of life among Hungarian teenagers? This section analyzes the relationship between the choice of metaphor and elements of the social context that were available as 
background variables in the questionnaire. These variables included basic characteristics of the school (i.e., type and location), information on the students' socio-demographic background and school performance, certain elements of individual media use, and how leisure time was spent (see Appendix 2). Due to the relatively small size of our sub-sample of source domains $(n=890)$ and the heavy-tail distribution of metaphors (i.e., low number of metaphors with greater frequencies and higher number of metaphors with very small frequencies), we had to apply certain restrictions in the analysis. Therefore, the following results are based only on the six most frequently used metaphors: GAME, FOOD, JOURNEY, CHALLENGE, PLANT and ROLLERCOASTER. These six metaphors amounted to $36 \%$ of the full metaphor sample. We treated the six metaphors as separate dummy variables; we compared the social profile of each individual metaphor to that of all of the other metaphors along the different categories of the background variables.

Table 3 shows the proportion of teenagers who chose one of the top six metaphors in the full sample of metaphors. Cells highlighted in grey in the table denote those subcategories where the relationship between the choice of metaphor and the background variable proved to be significant with generally small effect sizes. The plus (+) and minus (-) signs mark a single cell being above or below expectations based on adjusted residuals larger or smaller than 2 , respectively. In other words, a plus sign $(+)$ indicates that a metaphor is more frequent in that particular group than expected, while a minus sign (-) shows that it is less frequent. (Results of the Chi-square tests of independence and exact values of adjusted residuals are included in Appendix 3a and 3b. The higher the value, the more likely the variable is associated with the metaphor.)

The interpretation of the relationship between metaphors and background variables proved to be a challenging task. While certain patterns did appear for which we were able to offer a plausible interpretation, some of the trends that appeared in the data could not be accounted for due to the low sample size of the respective metaphors. Thus, our second hypothesis with regard to the influence of social factors on the choice of metaphorical source domains was not fully justified: according to our data, social factors do play a role in the selection of some metaphorical source domains (but not all).

What our results show is that the social profile of GAME and FOOD differs the most from all other metaphors in the sense that they are significantly over- or underrepresented along the categories of four to five contextual (background) variables. For JOURNEY and PLANT, the number of variables with a significant influence are only one to three, while CHALLENGE and ROLLERCOASTER are not associated in particular with any variable. Based on the data the following main observations can be made with regard to the interplay between sociodemographic factors and the choice of metaphorical source domain for the conceptualization of life:

1. We found the use of the GAME and FOOD metaphors was particularly influenced by socio-economic status (SES); these showed largely contrastive patterns. Thus, GAME was a more frequent choice among lower SES students, while FOOD was more prevalent among higher SES students. GAME was slightly overrepresented among students attending vocational (14.3\%) and secondary vocational schools (12.6\%), while it was rarer among teenagers whose mothers had a tertiary-level education (5.5\%). At the same time, FOOD showed just the opposite trend: it was overrepresented in grammar schools (10.8\%) and among students with highly educated mothers (10.3\%). The relationship between excessive internet use and the higher than expected formulation of GAME as a source domain on the one hand (11.3\%), and the nonfrequent watching of television and the selection of FOOD on the other hand (7.7\%) were also significant. Interestingly, school performance was also relevant. Taking the last available grade in Hungarian literature as an indicator of overall academic 
achievement, we could observe that poorer grades were associated with the use of both GAME and FOOD (12.3\% and 9.2\%). Among the top six metaphors, the role of gender appears to be significant only in the case of FOOD; it was a more frequent choice among males (8.9\%).

2. Similarly to FOOD, JOURNEY can also be associated with a higher SES status in the sense that it was overrepresented in grammar schools (9.6\%). It also appeared frequently among students who were categorized as non-frequent televiewers (7.7\%) and internet users $(7.1 \%)$.

3. In line with Kövecses' (2015: 100) hypothesis that the physical environment influences metaphorical conceptualizations, one of the most striking observations to emerge from our data was the overrepresentation of the PLANT metaphor among students who attended schools in smaller towns and villages (7.6\% and 6.9\%, respectively). In striking contrast, the metaphor was basically non-existent among students attending a school in Budapest, the capital of Hungary (0.9\%). These results suggest that the immediate physical environment in which one lives (such as closeness to nature) does significantly affect the choice of metaphorical conceptualization of life.

Second, social factors - in particular type and location of school, socio-economic status and media consumption - can have a weak but significant effect on the selection of source domains, thus lessening the importance of cultural history in shaping metaphorical conceptualizations of life.

Table 3. Social characteristics of the TOP 6 metaphors (\% of respondents who chose a particular metaphor in each sub-category of the background variables).

\begin{tabular}{|c|c|c|c|c|c|c|c|c|c|}
\hline & & \multicolumn{8}{|c|}{ METAPHOR } \\
\hline & & $\begin{array}{c}\text { 1. GAME } \\
(n=79)\end{array}$ & $\begin{array}{c}\text { 2. FOOD } \\
(n=56)\end{array}$ & $\begin{array}{c}3 . \\
\text { JOURNEY } \\
(n=50)\end{array}$ & $\begin{array}{c}4 . \\
\text { CHALLEN } \\
\text { GE } \\
(n=47)\end{array}$ & $\begin{array}{c}\text { 5. PLANT } \\
(n=44)\end{array}$ & $\begin{array}{c}6 . \\
\text { ROLLER- } \\
\text { COASTER } \\
(n=41)\end{array}$ & $\begin{array}{c}\text { TOP6 } \\
\text { METAPHO } \\
\text { RS IN } \\
\text { TOTAL } \\
(n=317)\end{array}$ & $\begin{array}{c}A L L \\
\text { METAPHO } \\
\text { RS } \\
(n=890)\end{array}$ \\
\hline \multirow{4}{*}{$\begin{array}{l}\text { Type of } \\
\text { school }\end{array}$} & Primary & $8.6 \%$ & $3.5 \%$ & $4.3 \%$ & $6.6 \%$ & $4.3 \%$ & $3.7 \%$ & $31.1 \%$ & $100 \%$ \\
\hline & Vocational & $14.3 \%(+)$ & $4.5 \%$ & $4.5 \%$ & $0.9 \%(-)$ & $8.0 \%$ & $3.6 \%$ & $35.7 \%$ & $100 \%$ \\
\hline & $\begin{array}{l}\text { Secondary } \\
\text { vocational }\end{array}$ & $12.6 \%(+)$ & $6.8 \%$ & $3.7 \%$ & $4.7 \%$ & $6.8 \%$ & $4.2 \%$ & $38.7 \%$ & $100 \%$ \\
\hline & Grammar & $3.8 \%(-)$ & $10.8 \%(+)$ & $9.6 \%(+)$ & $5.8 \%$ & $2.9 \%$ & $6.7 \%$ & $39.6 \%$ & $100 \%$ \\
\hline \multirow{4}{*}{$\begin{array}{r}\text { Type of } \\
\text { settlement } \\
\text { (school) }\end{array}$} & Budapest & $9.1 \%$ & $7.7 \%$ & $5.5 \%$ & $8.2 \%(+)$ & $0.9 \%(-)$ & $6.8 \%$ & $38.2 \%$ & $100 \%$ \\
\hline & Large city & $9.0 \%$ & $8.1 \%$ & $5.5 \%$ & $4.5 \%$ & $4.8 \%$ & $3.5 \%$ & $35.5 \%$ & $100 \%$ \\
\hline & Town & $7.9 \%$ & $4.0 \%(-)$ & $6.0 \%$ & $4.0 \%$ & $7.6 \%(+)$ & $4.3 \%$ & $33.8 \%$ & $100 \%$ \\
\hline & Village & $12.1 \%$ & $3.4 \%$ & $5.2 \%$ & $5.2 \%$ & $6.9 \%(+)$ & $3.4 \%$ & $36.2 \%$ & $100 \%$ \\
\hline \multirow{2}{*}{ Gender } & Male & $10.6 \%$ & $8.9 \%(+)$ & $4.7 \%$ & $4.0 \%$ & $5.3 \%$ & $3.5 \%$ & $37.0 \%$ & $100 \%$ \\
\hline & Female & $7.1 \%$ & $3.7 \%$ & $6.6 \%$ & $6.6 \%$ & $4.6 \%$ & $5.7 \%$ & $34.2 \%$ & $100 \%$ \\
\hline \multirow{3}{*}{$\begin{array}{r}\text { Mother's level } \\
\text { of education }\end{array}$} & Primary & $10.7 \%$ & $3.7 \%$ & $4.4 \%$ & $5.2 \%$ & $6.3 \%$ & $4.8 \%$ & $35.2 \%$ & $100 \%$ \\
\hline & Secondary & $9.5 \%$ & $6.3 \%$ & $5.0 \%$ & $5.9 \%$ & $4.5 \%$ & $2.7 \%$ & $33.9 \%$ & $100 \%$ \\
\hline & Tertiary & $5.5 \%(-)$ & $10.3 \%(+)$ & $7.6 \%$ & $4.1 \%$ & $4.8 \%$ & $6.9 \%$ & $39.3 \%$ & $100 \%$ \\
\hline \multirow{2}{*}{$\begin{array}{r}\text { Last available } \\
\text { grade in } \\
\text { Hungarian } \\
\text { literature }\end{array}$} & Excellent or good & $6.8 \%(-)$ & $5.2 \%(-)$ & $6.3 \%$ & $5.3 \%$ & $4.5 \%$ & $4.7 \%$ & $32.8 \%$ & $100 \%$ \\
\hline & $\begin{array}{l}\text { Satisfactory or } \\
\text { worse }\end{array}$ & $12.3 \%(+)$ & $9.2 \%(+)$ & $4.4 \%$ & $4.8 \%$ & $6.1 \%$ & $3.1 \%$ & $39.9 \%$ & $100 \%$ \\
\hline \multirow{2}{*}{$\begin{array}{l}\text { Watching } \\
\text { television }\end{array}$} & $\begin{array}{l}\text { Non-frequent } \\
\text { viewer }\end{array}$ & $9.1 \%$ & $7.7 \%(+)$ & $7.1 \%(+)$ & $4.8 \%$ & $4.3 \%$ & $4.6 \%$ & $37.5 \%$ & $100 \%$ \\
\hline & Frequent viewer & $8.5 \%$ & $4.0 \%(-)$ & $3.0 \%(-)$ & $6.1 \%$ & $6.1 \%$ & $4.6 \%$ & $32.3 \%$ & $100 \%$ \\
\hline
\end{tabular}


Cognitive Linguistics, Volume 29, Issue 1, Pages 121-154, ISSN (Online) 1613-3641, ISSN (Print) 0936-5907, DOI: https://doi.org/10.1515/cog-2016-0139.

\begin{tabular}{c|l|c|c|c|c|c|c|c|c|c}
\hline \multirow{2}{*}{ Internet use } & Non-frequent user & $6.9 \%(-)$ & $5.3 \%$ & $7.1 \%(+)$ & $4.3 \%$ & $4.9 \%$ & $4.7 \%$ & $33.1 \%$ & $100 \%$ \\
& Frequent user & $11.3 \%(+)$ & $7.6 \%$ & $3.8 \%(-)$ & $6.5 \%$ & $5.0 \%$ & $4.5 \%$ & $38.8 \%$ & $100 \%$ \\
\hline
\end{tabular}

\subsection{Verbalization of metaphorical conceptualizations of life}

One of the greatest tenets of Lakoff and Johnson (1980) is that metaphor is all-pervasive to our thinking and it is also a universal cognitive process. However, is everybody equally inclined to verbalize these conceptualizations? As far as we know, there has been no previous study to investigate the degree to which language users are inclined to verbalize conceptual metaphors, or what factors might affect this inclination. In order to answer this question, we compared the responses that we coded as a source domain for life with those responses where the question was either left blank (i.e., no text was provided) or where the participant did provide an answer, but this could not be coded as a source domain for life (see Appendix 1). The analysis was carried out along the same set of available background variables that were used to study social factors influencing the choice of certain metaphors (see previous section). We present the results broken down into the sub-sample of $7^{\text {th }}$ and $11^{\text {th }}$ graders. This partitioning of the original sample was necessary in order to ensure that important age-related differences (if any) remained visible.

The analysis shed interesting results (see Appendix 1). We found that the inclination to verbalize conceptual metaphors among the participants was dependent on age and type of school - the latter being a reflection of the academic hierarchy that is usually associated with the different types of secondary schools in Hungary. Thirty percent of primary school students provided a source domain, while this figure crept up to thirty-eight percent among secondary school students. Within this latter category, the proportion of source domains differed considerably, ranging from $29 \%$ in vocational schools to $46 \%$ in grammar schools. Secondary vocational schools were situated somewhere in the middle, at $36 \%$.

Figure 2 shows the percentages of students who provided a metaphorical source domain in each cohort, defined by the subgroups of those background variables where the relationship was significant for both $7^{\text {th }}$ and $11^{\text {th }}$ graders. (See Appendix 4 for the results of the statistical tests.) The relationship between the occurrence of a metaphorical source domain and all the contextual variables shown in the figure are significant at .05 level, based on a Chi-square test for independence. The vertical red lines denote the sub-sample means for the two age-groups. (See Appendix 4 for detailed statistics.) Our results suggest that students who attended schools located in villages generally underperformed in the formulation of a source domain, whereas in cities (especially in Budapest for $11^{\text {th }}$ graders) the proportion of students providing a metaphorical source domain was significantly higher.

Our data also suggest that the mother's level of education appears to have a major influence on the inclination to verbalize metaphorical conceptualizations. Primary school students with mothers who only have primary education were at the lower end of the verbalization scale (at 26\%); secondary school students whose mothers have tertiary education were at the upper end of the scale (at $48 \%$ ). School performance, measured by the last available grade in Hungarian literature, also had a clear influence: excellent (5) or good (4) grades, compared to satisfactory (3) or worse (2 or 1), anticipated a much higher likelihood for metaphors (38\% vs. $20 \%$ in the $7^{\text {th }}$ grade, and $46 \%$ vs. $32 \%$ in the $11^{\text {th }}$ grade). Watching television, as a rather passive form of media consumption on the one hand, and reading books (not school textbooks, but books for fun) on the other hand seem to have a contrasting influence. Students who were non-frequent viewers of television (i.e., who watched television for less than 3 hours per day on average) and who were also frequent readers (i.e., who read books at least a few times per week) were more inclined to provide a metaphorical source domain in their response. 
It seems fair to say that these variables - type of school, mother's level of education, academic performance and reading habits - surely go hand-in-hand, as they show exactly the same trend. This is not surprising, however: it can be reasonably assumed that students with college-educated parents are more likely to pursue their education in academically more prestigious institutions (such as grammar schools), where there is a greater variety of subjects and more reading to do. Nevertheless, this assumption does not quite explain our data. We hypothesize that the reasons also need to be sought in general language competence and skills. There is a significant body of research that has demonstrated the relation between SES and children's language development; children with a high SES mother show higher rates of language development than those with a low SES mother (Arriaga et al. 1998; Dollaghan et al. 1999; Hoff-Ginsberg 1991; Huttenlocher et al. 1991). ${ }^{18}$ Generally speaking, children with a higher SES mother perform better in all areas of language - they have larger vocabularies (Oller and Eilers 2002), perform better on tests measuring grammatical knowledge (Huttenlocher et al. 2002) and have better communicative style and skill (Hoff 2006). More importantly, and with even greater relevance for the present study, "children with less educated parents less frequently use language to analyze and reflect, to reason and justify, or to predict and consider alternative possibilities than children with more educated parents" (Hoff 2006: 62; emphasis by us). Our data seem to fit into these trends. Although we do not wish to question the pervasiveness of metaphor in thought, our results indicate that the inclination to verbalize metaphorical conceptualizations might be constrained by various factors, such as type of education and the mother's SES. Despite the fact that metaphor is primarily a conceptual device and not just a matter of language, it is nevertheless manifested most evidently in language. A greater competence in language (ranging across vocabulary, grammar, communicative skills, etc.) might provide a wider range of linguistic experience that can be utilized for “analysis and reflection” (to use Hoff's 2006 terms), which can then serve as a basis for the linguistic expression of metaphorical source domains.

18 SES is a complex variable that includes a number of features, such as level of education, household income, occupation, etc. Nevertheless, in studies of language development, SES is most typically based on the mother's level of education (Ensminger et al. 2003). 


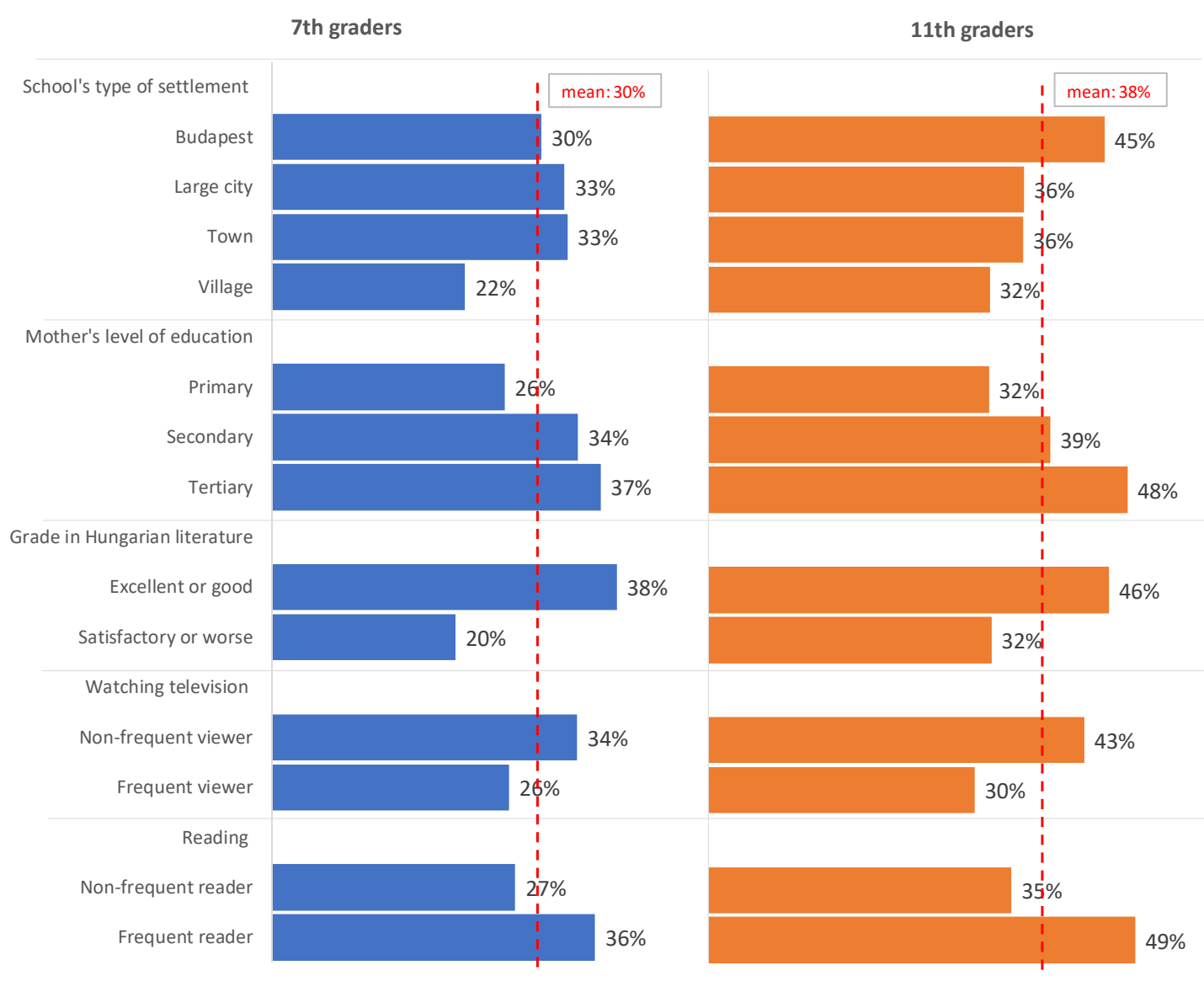

Figure 2. Proportion of teenagers providing an identifiable source domain for life in subgroups of contextual variables.

\section{Conclusions}

Previous cognitive research on the metaphorical conceptualization of life (e.g., Kövecses 2005; Schmidt and Brdar 2012) has stressed a) the significance (and overall dominance) of cultural history as a motivating factor in the emergence of metaphors; and accordingly b) Hungarians' more negative outlook on life. According to Kövecses (2005), this negative outlook was a consequence of the constant battles that Hungary had to fight throughout its long history; the experience left an imprint on social and cultural history, prompting Hungarians to view life primarily as a struggle and/or compromise. This paper set out to investigate the validity of these claims by drawing on the results of a nationwide survey of Hungarian $7^{\text {th }}$ and $11^{\text {th }}$ graders that was carried out in 2015 . Our hypotheses were the following: 1) the identified metaphors would be of a general character and no particularly prevalent, negative conceptualizations would emerge; 2) social factors would influence the choice of a particular concept as a source domain for conceptualizing life; and 3) the inclination to verbalize a concept as a source domain for life is not equally all-pervasive throughout a linguistic community but is dependent on social factors.

Regarding our first hypothesis, a direct comparison was not possible due to the different methodologies that were applied in the previous studies on Hungarian life metaphors. However, and generally speaking, the metaphors of 2015 did not reveal a particularly prevalent, negative mindset, but were rather reflections of the global concerns and interests of present-day youth. Optimism was a recurring theme within the answers - Hungarian teenagers seem to have a more-or-less positive outlook on life, in line with the World Value Survey results (which indicate relatively high happiness and life satisfaction values among young 
adults in Hungary, similarly to young adults in the USA). While many of the metaphors we uncovered - such as LIFE IS A GAME, LIFE IS A JOURNEY, LIFE IS A CHALLENGE or LIFE IS AN ADVENTURE - can be considered as typical and quite conventional conceptualizations, there was also a substantial number of metaphors that were unique to this particular survey, such as FOOD or ANIMAL. The prevalence and popularity of the FOOD metaphor was a rather surprising outcome of the research; the motivation behind this particular conceptualization remains to be clarified. Inspiration for the ANIMAL metaphor, however, might have originated in childhood stories, where there is an abundance of personified animals (further studies need to be carried out to investigate whether the ANIMAL metaphor is indeed age-dependent).

Our second hypothesis concerning the influence of social factors in the emergence of metaphorical conceptualizations for life has been partly justified; the type and the location of the school, socio-economic status and media consumption all proved to have an impact on the selection of some metaphors - in particular in the selection of GAME, FOOD, JOURNEY, PLANT and CHALLENGE. We do acknowledge the restricted nature of such results (which was due to our relatively small dataset and the weak statistical relationships); nevertheless, even this limited success does point to the necessity to re-evaluate the significance of the social context in metaphorical conceptualization, which has remained a "widely absent" (Dirven 2005: 40) area within cognitive linguistics (see also Geeraerts et al. 2010a).

With regard to our third hypothesis, our results suggest that social factors - especially type of school (at the secondary level), mother's level of education and academic achievement - do have an impact on speakers' inclination to verbalize metaphorical conceptualizations. From a sociological point of view, these findings more-or-less reflect the macro-level characteristics of the Hungarian education system. Evidence from cross-national research on education systems demonstrates that the degree of social segregation is particularly high in Hungary, and the public education system has very limited capacities to reduce the inequalities arising from social origin (OECD 2016). Competition for high-status students between primary schools contributes both to the emergence and the preservation of status-segregated, lowperforming schools, particularly in villages. Furthermore, the selection of students between vocational training and academically-oriented secondary tracks is largely determined by family background (Horn et al. 2016; Kertesi and Kézdi 2013).

Our study was a first, experimental step in applying survey methods common in sociology to metaphor research. Although the results do confirm the applicability of this framework, further research is necessary to explore the complexity of metaphorical conceptualization from a socio-variationist perspective. Expanding the sample by the inclusion of further age groups would be especially beneficial in teasing out generational differences (if any exist) in the use of life metaphors and thus arriving at a better understanding of (attitudes toward) life.

\section{Acknowledgements}

We wish to thank István Benczes, Kate Burridge, Laura A. Janda, Zoltán Kövecses and our three anonymous reviewers for their extremely helpful comments and suggestions. We also gratefully acknowledge the support of Péter Edvi, the Hungarian Scientific Research Fund (OTKA PD105354) and the International Children’s Safety Service (ICSS) Association.

\section{References}

Arriaga, R. J., L. Fenson, T. Cronan \& S. J. Pethick. 1998. Scores on the MacArthur Communicative Development Inventory of children from low- and middle-income families. Applied Psycholinguistics 19. 209-223.

Bourdieu, Pierre. 1986. The forms of capital. In John C. Richardson (ed.), The handbook of theory and research in for the sociology of education, 241-258. New York: Greenwood Press. 
Dirven, René. 2005. Major strands in cognitive linguistics. In: Francisco José Ruiz de Mendoza Ibáñez \& M. S. Peña Cervel (eds.), Cognitive linguistics: Internal dynamics and interdisciplinary interaction, 17-68. Berlin \& New York: Mouton de Gruyter.

Dollaghan, C. A., T. F. Campbell, J. L. Paradise, H. M. Feldman, J. E. Janosky \& D. N. Pitcairn. 1999. Maternal education and measures of early speech and language. Journal of Speech, Language and Hearing Research 42. 1432-1443.

Ensminger, Margaret E., Kate E. Fothergill, M.H. Bornstein \& R.H. Bradley. 2003. A decade of measuring SES: What it tells us and where to go from here. In: M. H. Bornstein \& R. H. Bradley (eds.), Socioeconomic status, parenting, and child development, 13-27. Mahwah, NJ: Lawrence Erlbaum.

Geeraerts, Dirk, Gitte Kristiansen \& Yves Peirsman. 2010a. Introduction: Advances in cognitive sociolinguistics. In: Dirk Geeraerts, Gitte Kristiansen \& Yves Peirsman (eds.), Advances in cognitive sociolinguistics, 1-19. Berlin \& New York: De Gruyter Mouton.

Geeraerts, Dirk, Gitte Kristiansen \& Yves Peirsman (eds.). 2010b. Advances in cognitive sociolinguistics. Berlin \& New York: De Gruyter Mouton.

Gibbs, Raymond W., Jr. 2007. Why cognitive linguists should care more about empirical methods. In: Monica Gonzalez-Marquez, Irene Mittelberg, Seana Coulson \& Michael J. Spivey (eds.), Methods in cognitive linguistics, 2-18. Amsterdam \& Philadelphia, PA: John Benjamins.

Hegedűs, Dániel. 2015. Life: burden or opportunity? A cognitive linguistic yet empirical approximation of living in Hungary. Term paper. Cultural Linguistics PhD programme. Budapest: Eötvös Loránd University.

Hoff, Erika. 2006. How social contexts support and shape language development. Developmental Review 26. 55-88.

Hoff-Ginsberg, E. 1991. Mother-child conversation in different social classes and communicative settings. Child Development 62. 782-796.

Hofstede, Geert. 2001. Culture's consequences: Comparing values, behaviors, institutions and organizations across nations. 2nd edition. Thousand Oaks, CA: Sage Publications.

Horn, Dániel, Tamás Keller \& Péter Róbert. 2016. Early tracking and competition: A recipe for major inequalities in Hungary. In: Hans-Peter Blossfeld, Sandra Buchholz, Jan Skopek \& Moris Triventi (eds.), Models of secondary education and social inequality: An international comparison, 129-147. Cheltenham \& Northampton: Edward Elgar.

Huttenlocher, J., W. Haight, A. Bryk, M. Seltzer \& T. Lyons. 1991. Early vocabulary growth: Relation to input and gender. Developmental Psychology 27. 236-248.

Huttenlocher, J., M. Vasilyeva, E. Cymerman \& S. Levine. 2002. Language input at home and at school: Relation to child syntax. Cognitive Psychology 45. 337-374.

Inglehart, Ronald. 1997. Modernization and postmodernization: Cultural, economic, and political change in 43 Societies. Princeton, NJ: Princeton University Press.

Katz, Albert N. \& Tamsen E. Taylor. 2008. The journeys of life: Examining a conceptual metaphor with semantic and episodic memory recall. Metaphor and Symbol 23. 148173.

Kertesi, G. \& G. Kézdi. 2013. School segregation, school choice and educational policies in 100 Hungarian towns. Budapest Working Papers 12. 1-134.

Knack, S. \& P. Keefer. 1997. Does social capital have an economic payoff? A cross-country investigation. The Quarterly Journal of Economics 112(4). 1251-1288.

Kövecses, Zoltán. 2002/2010. Metaphor: A practical introduction. 2nd edition. Oxford: Oxford University Press.

Kövecses, Zoltán. 2005. Metaphor in culture: universality and variation. Cambridge: Cambridge University Press. 
Kövecses, Zoltán. 2006. Language, mind, and culture: A practical introduction. Oxford: Oxford University Press.

Kövecses, Zoltán. 2015. Where metaphors come from: Reconsidering context in metaphor. Oxford: Oxford University Press.

Köves, Nikoletta. 2002. Hungarian and American dreamworks of life. Term paper. Department of American Studies. Budapest: Eötvös Loránd University.

Kristiansen, Gitte and René Dirven. 2008. Cognitive Sociolinguistics: Language variation, cultural models, social systems. Berlin \& New York: Mouton de Gruyter.

Kuczok, Marcin. 2017, in press. Precious possession, war or journey? Conceptual metaphors for LIFE in American English, Hungarian and Polish. In: Bożena Cetnarowska, Marcin Kuczok \& Marcin Zabawa (eds.), Various dimensions of contrastive studies. Katowice: Wydawnictwo Uniwersytetu Śląskiego. Paper downloaded from http://www.researchgate.net (accessed 03 July 2017).

Lakoff, George \& Mark Johnson. 1980. Metaphors we live by. Chicago and London: The University of Chicago Press.

Lakoff, George \& Mark Turner. 1989. More than cool reason: A field guide to poetic metaphor. Chicago and London: The University of Chicago Press.

Lester, David \& John F. Gunn. 2011a. National anthems and suicide rates. Psychological Reports 108. 43-44.

Lester, David \& John F. Gunn. 2011b. Lyrics of national anthems and suicide rates. Psychological Reports 109(1). 137-138.

OECD. 2016. PISA 2015 Results (Volume I): Excellence and equity in education. Paris: OECD Publishing.

Oller, D. K. \& R. E. Eilers. 2002. Language and literacy in bilingual children. Clevedon: Mutilingual Matters.

Özçalişkan, Şeyda. 2003. In a caravanserai with two doors I am walking day and night: Metaphors of death and life in Turkish. Cognitive Linguistics 14(4). 281-320.

Peng, Chao-Ying Joanne, Kuk Lida Lee \& Gary M. Ingersoll. 2002. An introduction to logistic regression analysis and reporting. The Journal of Educational Research 96(1). 3-14.

Pryor, F. L. 2005. National values and economic growth. The American Journal of Economics and Sociology 64(2). 451-483.

Pütz, Martin, Justyna A. Robinson \& Monika Reif (eds.). 2014. Cognitive sociolinguistics: Social and cultural variation in cognition and language use. Amsterdam \& Philadelphia, PA: John Benjamins.

Rokeach, M. 1973. The nature of human values. New York: Free Press.

Schmidt, Goran \& Mario Brdar. 2012. Variation in the linguistic expression of the conceptual metaphor LIFE IS A (GAMBLING) GAME. In: Mario Brdar, Ida Raffaelli \& Milena Žic Fuchs (eds.), Cognitive linguistics between universality and variation, 271-292. Cambridge: Cambridge Scholars Publishing.

Schwartz, S. H. 2007. Value orientations: Measurement, antecendents and consequences across nations. In R. Jowell, C. Roberts, E. Fitzgerald \& G. Eva (eds.), Measuring attitudes cross-nationally: Lessons from the European Social Survey, 169-204. London: Sage.

Vörös, Viktor, Péter Osváth, Orsolya Vincze, Katalin Pusztay, Sándor Fekete \& Zoltán Rihmer. 2012. Nemzeti himnuszok szóhasználata és tartalomelemzése: Előzetes eredmények egy transzkulturális szuicidum vizsgálatából [Word choice and content analysis of national anthems: Preliminary results of transcultural suicide]. Psychiatria Hungarica 27(3). 174-179. 
Cognitive Linguistics, Volume 29, Issue 1, Pages 121-154, ISSN (Online) 1613-3641, ISSN (Print) 0936-5907, DOI: https://doi.org/10.1515/cog-2016-0139.

Wardaugh, Ronald and Janet M. Fuller. 2015. An introduction to sociolingusitics. $7^{\text {th }}$ edition. Chichester: John Wiley and Sons.

Wierzbicka, Anna. 1988. The semantics of grammar. Amsterdam: John Benjamins.

Yu, Ning \& Dingding Jia. 2016. Metaphor in culture: LIFE IS A SHOW in Chinese. Cognitive Linguistics 27(2). 147-180. 
Appendix 1. Distribution of "Blank", "Other" and "Metaphor"* responses broken down by age group and type of school.

\begin{tabular}{c|c|c|c|c} 
& Blank & Other & Metaphor & Total \\
\hline Primary school $(n=1,158)$ & $49.9 \%$ & $20.0 \%$ & $30.1 \%$ & $100 \%$ \\
\hline Secondary school $(n=1,436)$ & $47.8 \%$ & $14.2 \%$ & $38.0 \%$ & $100 \%$ \\
\hline Vocational school $(n=387)$ & $57.4 \%$ & $13.7 \%$ & $28.9 \%$ & $100 \%$ \\
\hline Secondary vocational school $(n=528)$ & $48.5 \%$ & $15.3 \%$ & $36.2 \%$ & $100 \%$ \\
\hline Grammar school $(n=521)$ & $40.3 \%$ & $13.6 \%$ & $46.1 \%$ & $100 \%$ \\
\hline Total $(n=2,594)$ & $48.8 \%$ & $16.8 \%$ & $34.4 \%$ & $100 \%$
\end{tabular}

* "Blank": No answer was provided; "Other: Answer was provided, but it could not be coded as an identifiable source domain; "Metaphor": Answer could be coded as an identifiable source domain.

Appendix 2. List of background variables and their categories.

\begin{tabular}{|c|c|c|c|}
\hline & & VARIABLE & CATEgories \\
\hline \multirow{2}{*}{\multicolumn{2}{|c|}{ Institutional level }} & Type of school & $\begin{array}{l}\text { (1) primary, (2) vocational, (3) secondary vocational, (4) } \\
\text { grammar }\end{array}$ \\
\hline & & $\begin{array}{l}\text { Location of school } \\
\text { (type of settlement) }\end{array}$ & (1) Budapest, (2) city, (3) town, (4) village \\
\hline \multirow{9}{*}{ 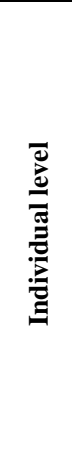 } & Socio- & Age group & (1) $7^{\text {th }}$ graders, (2) $11^{\text {th }}$ graders \\
\hline & demographic & Gender & (1) male, (2) female \\
\hline & background & Mother's highest level of education & (1) primary, (2) secondary, (3) tertiary \\
\hline & \multirow{2}{*}{$\begin{array}{l}\text { Academic } \\
\text { performance }\end{array}$} & Last available grade in Hungarian literature & $\begin{array}{l}\text { (1) satisfactory or worse (grade } 3 \text { to 1), } \\
\text { (2) excellent or good (grade } 5 \text { to 4) }\end{array}$ \\
\hline & & Last available grade in math & $\begin{array}{l}\text { (1) satisfactory or worse (grade } 3 \text { to 1), } \\
\text { (2) excellent or good (grade } 5 \text { to } 4 \text { ) }\end{array}$ \\
\hline & \multirow{4}{*}{$\begin{array}{l}\text { Media use \& } \\
\text { leisure time } \\
\text { activities }\end{array}$} & Watching television & $\begin{array}{l}\text { (1) non-frequent viewer (less than } 3 \text { hours per day), } \\
\text { (2) frequent viewer (more than } 3 \text { hours per day) }\end{array}$ \\
\hline & & Internet use & $\begin{array}{l}\text { (1) non-frequent user (less than } 3 \text { hours per day), } \\
\text { (2) frequent user (more than } 3 \text { hours per day) }\end{array}$ \\
\hline & & Video and online gaming & (1) non-daily gamer, (2) daily gamer \\
\hline & & Reading & $\begin{array}{l}\text { (1) non-frequent reader (less than few times a week), } \\
\text { (2) frequent reader (at least few times a week) }\end{array}$ \\
\hline
\end{tabular}

Appendix 3a. Results of Chi-square tests for independence between the choice of metaphor and social factors for Table 3 .

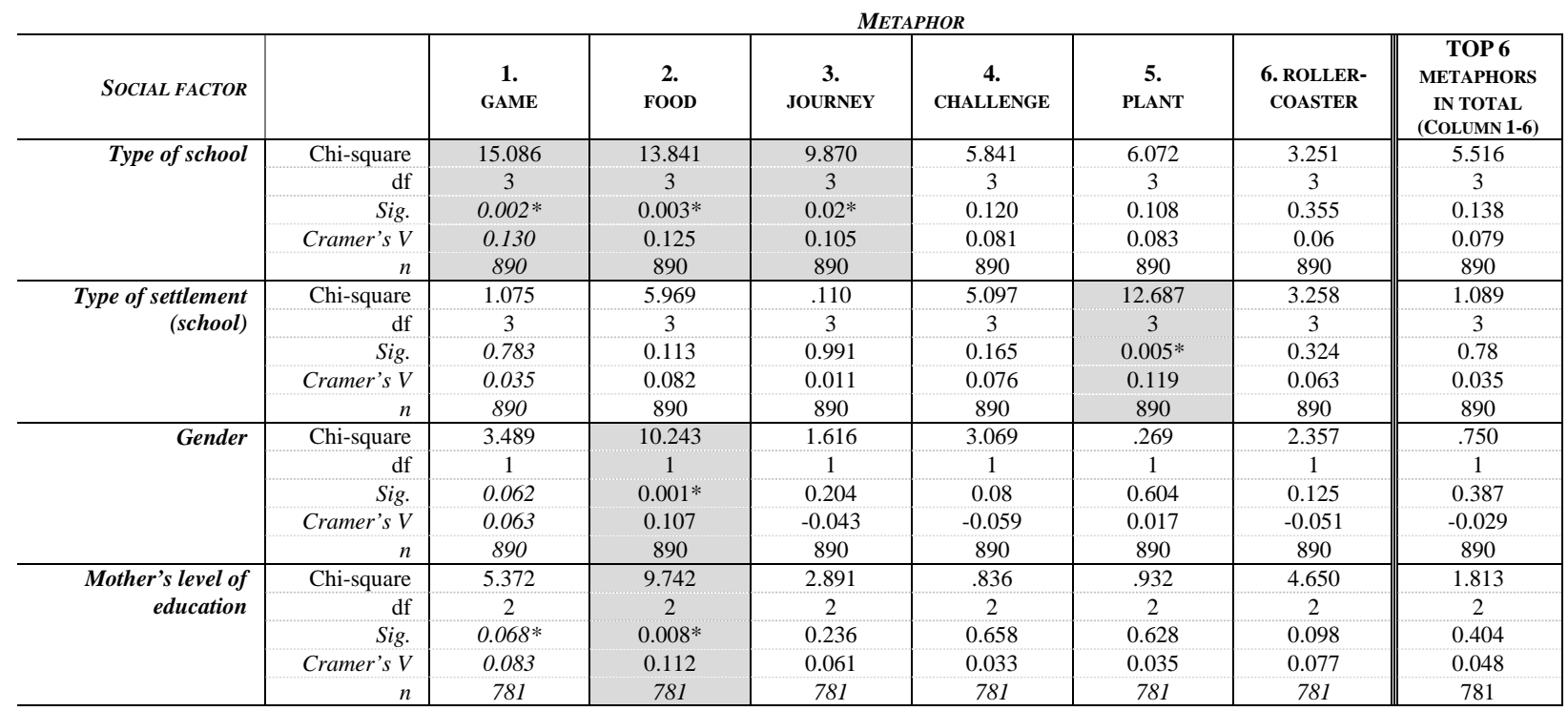


Cognitive Linguistics, Volume 29, Issue 1, Pages 121-154, ISSN (Online) 1613-3641, ISSN (Print) 0936-5907, DOI: https://doi.org/10.1515/cog-2016-0139.

\begin{tabular}{|c|c|c|c|c|c|c|c|c|}
\hline $\begin{array}{r}\text { Last available grade } \\
\text { in Hungarian } \\
\text { literature }\end{array}$ & $\begin{array}{r}\text { Chi-square } \\
\mathrm{df} \\
\text { Sig. } \\
\text { Cramer's } V \\
n\end{array}$ & $\begin{array}{c}6.601 \\
1 \\
0.01 * \\
0.088 \\
846\end{array}$ & $\begin{array}{c}4.612 \\
1 \\
0.032 * \\
0.074 \\
846\end{array}$ & $\begin{array}{c}1.131 \\
1 \\
0.288 \\
-0.037 \\
846\end{array}$ & $\begin{array}{c}.090 \\
1 \\
0.765 \\
-0.01 \\
846\end{array}$ & $\begin{array}{c}.915 \\
1 \\
0.339 \\
0.033 \\
846\end{array}$ & $\begin{array}{c}1.076 \\
1 \\
0.3 \\
-0.036 \\
846\end{array}$ & $\begin{array}{c}3.666 \\
1 \\
0.056 \\
-0.066 \\
846\end{array}$ \\
\hline Watching television & $\begin{array}{r}\text { Chi-square } \\
\text { df } \\
\text { Sig. } \\
\text { Cramer's } V \\
n\end{array}$ & $\begin{array}{c}.074 \\
1 \\
0.785 \\
0.009 \\
890 \\
\end{array}$ & $\begin{array}{c}4.777 \\
1 \\
0.029 * \\
0.073 \\
890\end{array}$ & $\begin{array}{c}6.466 \\
1 \\
0.011^{*} \\
0.085 \\
890 \\
\end{array}$ & $\begin{array}{c}.693 \\
1 \\
0.405 \\
-0.028 \\
890\end{array}$ & $\begin{array}{c}1.471 \\
1 \\
0.225 \\
-0.041 \\
890 \\
\end{array}$ & $\begin{array}{c}.001 \\
1 \\
0.971 \\
0.001 \\
890 \\
\end{array}$ & $\begin{array}{c}2.468 \\
1 \\
0.116 \\
-0.053 \\
890 \\
\end{array}$ \\
\hline Internet use & $\begin{array}{r}\text { Chi-square } \\
\mathrm{df} \\
\text { Sig. } \\
\text { Cramer's } V \\
n\end{array}$ & $\begin{array}{c}5.356 \\
1 \\
0.021^{*} \\
-0.078 \\
890\end{array}$ & $\begin{array}{c}1.944 \\
1 \\
0.163 \\
-0.047 \\
890\end{array}$ & $\begin{array}{c}4.574 \\
1 \\
0.032 * \\
0.072 \\
890\end{array}$ & $\begin{array}{c}2.305 \\
1 \\
0.129 \\
-0.051 \\
890\end{array}$ & $\begin{array}{c}.013 \\
1 \\
0.908 \\
-0.004 \\
890\end{array}$ & $\begin{array}{c}.009 \\
1 \\
0.926 \\
0.003 \\
890\end{array}$ & $\begin{array}{c}3.146 \\
1 \\
0.076 \\
0.059 \\
890\end{array}$ \\
\hline
\end{tabular}

* The Chi-square statistics are significant at the .05 level.

Dependent (column) variables are dummies, where $1=$ respective TOP 6 metaphor, $0=$ all other metaphors.

Variables in "Age group", "Last available grade in math" and "Video and online gaming" do not show a significant relationship with any of the TOP 6 metaphors; these variables have been omitted from Table 3.

Appendix 3b. Adjusted residuals for Table 3.

\begin{tabular}{|c|c|c|c|c|c|c|c|}
\hline & & \multicolumn{6}{|c|}{ METAPHOR } \\
\hline SOCIAL FACTOR & & $\begin{array}{c}1 . \\
\text { GAME }\end{array}$ & $\begin{array}{c}2 . \\
\text { FOOD }\end{array}$ & $\begin{array}{c}3 . \\
\text { JOURNEY } \\
\end{array}$ & $\begin{array}{c}4 . \\
\text { CHALLENGE } \\
\end{array}$ & $\begin{array}{c}5 . \\
\text { PLANT }\end{array}$ & $\begin{array}{l}\text { 6. ROLLER- } \\
\text { COASTER }\end{array}$ \\
\hline \multirow{4}{*}{ Type of school } & Primary & -0.20 & -2.80 & -1.30 & 1.40 & -0.70 & -1.00 \\
\hline & Vocational & 2.20 & -0.90 & -0.60 & -2.20 & 1.60 & -0.60 \\
\hline & $\begin{array}{l}\text { Secondary } \\
\text { vocational }\end{array}$ & 2.00 & 0.30 & -1.30 & -0.40 & 1.30 & -0.30 \\
\hline & Grammar & -3.30 & 3.40 & 3.10 & 0.40 & -1.70 & 1.80 \\
\hline \multirow{4}{*}{ Type of settlement (school) } & Budapest & 0.10 & 1.00 & -0.10 & 2.20 & -3.20 & 1.80 \\
\hline & Large city & 0.10 & 1.60 & -0.10 & -0.70 & -0.10 & -1.10 \\
\hline & Town & -0.70 & -2.00 & 0.30 & -1.20 & 2.60 & -0.30 \\
\hline & Village & 0.90 & -0.90 & -0.20 & 0.00 & 0.70 & -0.40 \\
\hline \multirow{2}{*}{ Gender } & Male & 1.90 & 3.20 & -1.30 & -1.80 & 0.50 & -1.50 \\
\hline & Female & -1.90 & -3.20 & 1.30 & 1.80 & -0.50 & 1.50 \\
\hline \multirow{3}{*}{ Mother's level of education } & Primary & 1.70 & -2.60 & -1.10 & 0.20 & 1.00 & -0.20 \\
\hline & Secondary & 0.70 & -0.40 & -0.60 & 0.70 & -0.60 & -1.80 \\
\hline & Tertiary & -2.30 & 2.90 & 1.70 & -0.80 & -0.40 & 1.90 \\
\hline \multirow{2}{*}{$\begin{array}{l}\text { Last available grade in } \\
\text { Hungarian literature }\end{array}$} & Good or excellent & -2.60 & -2.10 & 1.10 & 0.30 & -1.00 & 1.00 \\
\hline & Satisfactory or worse & 2.60 & 2.10 & -1.10 & -0.30 & 1.00 & -1.00 \\
\hline \multirow{2}{*}{ Watching television } & Non-frequent viewer & 0.30 & 2.20 & 2.50 & -0.80 & -1.20 & 0.00 \\
\hline & Frequent viewer & -0.30 & -2.20 & -2.50 & 0.80 & 1.20 & 0.00 \\
\hline \multirow{2}{*}{ Internet use } & Non-frequent user & -2.30 & -1.40 & 2.10 & -1.50 & -0.10 & 0.10 \\
\hline & Frequent user & 2.30 & 1.40 & -2.10 & 1.50 & 0.10 & -0.10 \\
\hline
\end{tabular}

* Contextual factors with a significant relationship and with values more than 2.0 or less than 2.0 are highlighted in grey.

Appendix 4. Results of Chi-square test for independence between metaphorical conceptualization and social factors (Figure 2).

\begin{tabular}{|c|c|c|c|}
\hline \multicolumn{2}{|l|}{ CONTEXTUAL VARIABLE } & \multirow[t]{2}{*}{$7^{T H}$ GRADERS } & $1^{\text {1H }}$ GRADERS \\
\hline Type of school & Chi-square & & 30.912 \\
\hline & $\mathrm{df}$ & & 2 \\
\hline & Sig. & NOT RELEVANT & $.000, *$ \\
\hline & Cramer's V & & 147 \\
\hline & $n$ & & 1426 \\
\hline \multirow[t]{5}{*}{ Type of settlement (school) } & Chi-square & 10.678 & 9.738 \\
\hline & df & 3 & 3 \\
\hline & Sig. & $0.014 *$ & $0.021 *$ \\
\hline & Cramer's V & .096 & .083 \\
\hline & $n$ & 1161 & 1426 \\
\hline Gender & Chi-square & 4.030 & 0.223 \\
\hline & $\mathrm{df}$ & 1 & 1 \\
\hline
\end{tabular}


Cognitive Linguistics, Volume 29, Issue 1, Pages 121-154, ISSN (Online) 1613-3641, ISSN (Print) 0936-5907, DOI: https://doi.org/10.1515/cog-2016-0139.

\begin{tabular}{|c|c|c|c|}
\hline & $\begin{array}{r}\text { Sig. } \\
\text { Cramer's } V \\
n\end{array}$ & $\begin{array}{c}0.045 * \\
.059 \\
1159\end{array}$ & $\begin{array}{c}0.637 \\
.013 \\
1422\end{array}$ \\
\hline \multirow[t]{5}{*}{ Mother's level of education } & Chi-square & 8.961 & 24.574 \\
\hline & df & 2 & 2 \\
\hline & Sig. & $0.011 *$ & $.000 *$ \\
\hline & Cramer's V & .104 & .135 \\
\hline & $n$ & 831 & 1346 \\
\hline \multirow{5}{*}{$\begin{array}{r}\text { Last available grade in Hungarian } \\
\text { literature }\end{array}$} & Chi-square & 31.496 & 23.134 \\
\hline & & 1 & 1 \\
\hline & Sig. & $.000^{*}$ & $.000 *$ \\
\hline & Cramer's V & .176 & .135 \\
\hline & $n$ & 1018 & 1271 \\
\hline \multirow[t]{5}{*}{ Last available grade in math } & Chi-square & 18.107 & 7.015 \\
\hline & & 1 & 1 \\
\hline & Sig. & $.000^{*}$ & $.008 *$ \\
\hline & Cramer's V & .133 & .074 \\
\hline & $n$ & 1021 & 1266 \\
\hline \multirow[t]{5}{*}{ Watching television } & Chi-square & 8.001 & 22.105 \\
\hline & df & 1 & 1 \\
\hline & Sig. & $.005^{*}$ & $.000 *$ \\
\hline & Cramer's V & -.083 & -.125 \\
\hline & $n$ & 1161 & 1426 \\
\hline \multirow[t]{5}{*}{ Internet use } & Chi-square & 5.711 & 2.545 \\
\hline & $\mathrm{df}$ & 1 & 1 \\
\hline & Sig. & $0.017 *$ & 0.111 \\
\hline & Cramer's V & -.070 & -.042 \\
\hline & $n$ & 1161 & 1426 \\
\hline \multirow[t]{5}{*}{ Video and online gaming } & Chi-square & 0.181 & 0.511 \\
\hline & df & 1 & 1 \\
\hline & Sig. & 0.671 & 0.475 \\
\hline & Cramer's V & -.012 & -.019 \\
\hline & $n$ & 1161 & 1426 \\
\hline \multirow[t]{5}{*}{ Reading habits } & Chi-square & 9.537 & 22.368 \\
\hline & df & 1 & 1 \\
\hline & Sig. & $.002 *$ & $.000 *$ \\
\hline & Cramer's V & .091 & .125 \\
\hline & $n$ & 1161 & 1426 \\
\hline
\end{tabular}

* The Chi-square statistic is significant at the .05 level.

Cells in grey signify significant relationships. 